\title{
POLITICI EDUCAȚIONALE
}

https://doi.org/10.52387/1811-5470.2021.1.17

CZU: 373.015:343.54

\section{VULNERABILITATEA ELEVILOR LA RISCURILE TRAFICULUI DE FIINȚE UMANE}

IUrie UNGUREANU, doctor, profesor Liceul Teoretic „B.P. Hasdeu”, mun. Bălți

ORCID iD: 0000-0003-4183-7029

Ala VECHIU-GHERMAN, specialist în domeniul antitrafic, master Universitatea „Al.I. Cuza” din Iași, România

ORCID iD: 0000-0001-6660-8420

Rodica UNGUREANU, profesoară Școala Profesională Nr. 3, mun. Bălți ORCID iD: 0000-0001-7660-0924

Rezumat. Prezentul articol elucidează factorii determinanți ai vulnerabilității elevilor și tinerilor față de fenomenul traficului de ființe umane și definesste riscurile și consecințele acestui flagel în rândul elevilor. Studiul este o inițiativă comună a reprezentanților mediului academic și al celui antitrafic de-a analiza profilul elevilor și de-a releva o serie de cauze și consecințe ce pot avea corelare cu traficul de ființe umane.

Pe final, sunt generate concluzii și recomandări, menite să îmbunătățească intervenția școlii în prevenția riscului exploatării în rândul elevilor, pentru a contribui la creșterea gradului de conștientizare a gravității fenomenului față de ei.

Cuvinte-cheie: trafic de ființe umane, elevi, școală, vulnerabilitate, factori de risc, consecințe.

\section{VULNERABILITY OF STUDENTS TO THE RISKS OF TRAFFICKING IN HUMAN BEINGS}

Abstract. This article elucidates the determinant factors of the vulnerability of students and youth to the phenomenon of trafficking in human beings and defines the risks and consequences of this scourge among students. Moreover, this article represents a joint initiative between representatives of academic environment and of the anti-trafficking field to analyze the profile of students and to emphasize a series of factors which may correlate with trafficking in human beings.

Last but not least, a series of conclusions and recommendations aimed at improving the school's intervention to prevent the risk of exploitation among students and to contribute to raising awareness of the seriousness of the phenomenon among youth are generated at the end of this article.

Keywords: trafficking in human beings, students, school, prevention, vulnerability, risk factors, consequences.

Traficul de fiinte umane este recunoscut pe plan internațional drept o infracțiune și o încălcare gravă a drepturilor fundamentale ale omului. Republica Moldova nu este o excepție, fiind o țară de origine, de tranzit, dar și de destinație a fenomenului în cauză. Acest lucru se datorează nivelului redus al bunăstării populației, migrației masive și a noii generații de copii rămași fără îngrijire părintească, în urma exodului părinților, discriminării în bază de gen, informării insuficiente, violenței în familie, lipsei unei educații bazate pe „gândirea critică”, dar și altor factori interni sau externi.

Statisticile arată că numărul copiilor identificați ca fiind afectați de fenomenul traficului s-a dublat, 
în ultimii ani. Din grupul-țintă fac parte elevii din școlile profesionale, cu vârste între adolescență și maturitate. Acești copii - printre ei, în egală măsură, fete și băieți - sunt expuși unui risc sporit de a deveni victime ale fenomenului traficului de fiinte umane, atât în interiorul, cât și în afara țării. Consecintele, adesea, sunt dramatice. Integrarea ulterioară în comunitate a victimelor minore (sau aproape mature) este extrem de dificilă și necesită eforturi și mijloace considerabile atât din partea societății, cât și a celor vizați.

Un rol important în anticiparea tuturor formelor de manifestare și tendințelor fenomenului analizat, de prevenire și combatere activă a acestuia, i se atribuie comunității internaționale, autorităților naționale și mediului academic.

\section{Definiții socio-juridice privind traficul de fiinte umane}

Noțiunea „traficul de copii”, în opinia specialiștilor, semnifică recrutarea, transportarea, transferul, adăpostirea sau primirea unui copil, precum și darea sau primirea unor plăți ori beneficii pentru obținerea consimțământului unei persoane care deține controlul asupra copilului, în scopul:

- exploatării sexuale, comerciale și necomerciale, în prostituție sau în industria pornografică;

- exploatării prin muncă sau serviciilor forțate;

- practicării cerșetoriei sau în alte scopuri josnice;

- exploatării în sclavie sau în condiții similare sclaviei, inclusiv în cazul adopției ilegale;

- folosirii în conflicte armate;

- folosirii în activitate criminală;

- prelevării organelor sau țesuturilor umane;

- abandonării în străinătate, vânzării sau cumpărării.

Victima traficului de ființe umane / copii este persoană fizică ce a avut de suferit în rezultatul traficului de ființe umane / copii [16].

\section{Conceptul de vulnerabilitate în contextul riscurilor}

Relevanța este justificată de necesitatea elucidării conceptelor privind vulnerabilitatea potențialelor victime ale traficului de ființe umane, abuzul, poziția de vulnerabilitate, riscurile și consecințele fenomenului: noțiuni frecvent întâlnite în literatura de specialitate, dar care necesită a fi explicate, în context specific.

Termenul de vulnerabilitate se regăsește, în primul rând, în Convenția Consiliului Europei privind lupta împotriva traficului de ființe umane, ce prevede că „fiecare stat parte se va asigura că serviciile sunt furnizate cu acordul și cu informarea victimelor, luând în considerare nevoile specifice ale persoanelor vulnerabile și drepturile copiilor privind cazarea, educația și îngrijirile medicale potrivite" [6].

Cu toate acestea, testarea abuzului în ceea ce privește poziția de vulnerabilitate este una dintre cele mai provocatoare aspecte în procesul judiciar, dar și în cel de asistență și protecție a victimelor traficului de ființe umane, datorită faptului că noțiunea de vulnerabilitate poate fi probată prin elemente ce întrunesc fapte, circumstanțe ce fac o persoană vulnerabilă [14, p. 19].

Unul dintre obiectivele Planului național de actiuni de prevenire și combatere a traficului de ființe umane din Republica Moldova a fost reducerea vulnerabilității persoanelor aflate în dificultate, inclusiv copii din școlile-internat și școlile profesionale reprezentând unul dintre grupurile țintă vizate [10, p. 13].

Pe de altă parte, în subordinea Ministerului Educației, Culturii și Cercetării se află 47 de instituții de învățământ profesional tehnic secundar, a căror prezență și grup-țintă nu se regăsește în documentele de politici anti-trafic [7, pp. 1-4].

În Raportul World Vision România, se menționează că printre cele mai vulnerabile categorii de populație expuse riscului de a fi traficate sunt copiii din familiile unde, cel puțin unul dintre părinți este plecat în străinătate [2, p. 19]. În același document se arată că o altă categorie afectată o reprezintă și adolescenții din grupurile școlare / școlile de artă și meserii / școlile profesionale care întrunesc cea mai mare parte a factorilor de risc evidențiați în discutiile cu reprezentantii instituțiilor scolare. Conform raportului menționat, cei mai mulți elevi provin din familii cu posibilități materiale reduse și grad de educație scăzut, adesea cu stereotipuri bine implantate și crezând mituri privin d fenomenul traficului de ființe umane de felul că „mie asta nu mi se poate întâmpla". Perspectivele reușitei în viață ale acestor elevi sunt minime, iar intenția lor de a migra în afara țării în scop de muncă este un fenomen [ibidem, p. 20].

În cadrul unui studiu asupra procesului de recrutare a minorilor, realizat de Inspectoratul General al Poliției Române în parteneriat cu Agenția Națională împotriva Traficului de Persoane, se face referire la faptul că acordarea unei priorități scăzute pentru educație și formare profesională contribuie la manifestarea unei atitudini pasive, lipsită de interes și motivație, făcându-i astfel copii vulnerabili, dar și susceptibili față de traficul de ființe umane, fiind 
ademeniți prin oferirea de bunuri sau promisiuni pentru o viață mai bună și astfel crește riscul de a fi traficați" [1, pp. 48-49].

Vulnerabilitatea se referă inclusiv la factorii de context și mediu ce cresc susceptibilitatea unui individ sau a unui grup la traficul de persoane, care în consecință violează drepturile fundamentale ale omului. Aceste cauze deși sunt cunoscute, predomină și rămân a fi clasice anume în condițiile sărăciei, inegalității la angajarea în câmpul muncii, experienței de violență în familie, lipsei informării și a educației $[3 ; 13$, p. 13].

În consecință, factorii respectivi favorizează acțiunile traficanților de a aplica metodele cele mai des întâlnite de racolare, precum înșelăciunea și abuzul privind poziția de vulnerabilitate.

Mai mult decât atât, F. Zanfirescu menționează că vulnerabilitatea la trafic rezultă din factorii economici și sociali, precum sunt sărăcia, discriminarea în bază de gen, violența în familie, familiile disfuncționale, conflictele armate, dar și factorii personali ca de pildă, ocupația, vârsta, starea de sănătate, sexul $[8 ; 17$, p. 26].

În atare context, experții Centrului Internațional „La Strada” din Republica Moldova susțin că factori precum sistemul social degradant și feminizarea sărăciei conduc la vulnerabilitatea victimei, din perspective diferite, cum ar fi:

- reducerea posibilităților de a-și continua studiile,

- micșorarea numărului locurilor de muncă,

- posibilități de independența materială reduse în raport cu familia din care provin,

- abuzul și disfuncționalitatea în cadrul familiei [4, pp. 28-30].

\section{Riscuri și consecințe ale traficului de ființe umane în rândul elevilor}

Traficul de ființe umane reprezintă un fenomen complex, interdependent de factori socioeducaționali, economici și culturali ce afectează nucleul activ al societății, în special, femeile și copiii, dar și bărbații. Pe de altă parte, monitorizarea insuficientă a acestui flagel, dar și resursele informaționale și financiare limitate reduc șansele elevilor de a se afirma, de a reuși, de a obține o profesie ce le-ar permite un nivel al bunăstării care să acopere mai mult decât necesitățile de bază.

Teoria marginalizării și excluziunii sociale din ce cauze indivizii, între care și elevii, adesea marginalizați sub aspecte sociale și educațional, ajung în categoria cea mai vulnerabilă, supusă procesului victimizării traficului de ființe umane. Totodată, este ne- cesară distincția clară dintre sărăcie și excluziunea socială, primul concept însemnând lipsa de resurse materiale, de venituri financiare, în timp ce cea de a doua noțiune se referă la o arie mai largă de grupuri dezavantajate.

Definirea exactă a grupurilor dezavantajate diferă, în funcție de specificul fiecărei societăți. Cert este faptul că excluziunea socială vizează mai multe probleme sociale și, desigur, cele ale victimelor traficului de ființe umane. Ea denotă lipsa oportunităților și a șanselor egale de participare a indivizilor la diferite activități ale vieții sociale, precum angajarea pe piața muncii, accesul la servicii publice, la viața politică, precum și forme diverse de discriminare, izolarea fizică față de semeni [12, p. 322].

Invocând în acest articol Teoria anomiei a lui E. Durkheim, menționăm că starea de anomie, dezordinea, dezorganizarea în Republica Moldova se explică prin exodul de amploare a cetățenilor noștri.

Deși se discută despre o tendință de normalizare a dinamicii infracționalității în Republica Moldova, aceasta rămâne a fi persistentă și surprinde prin forme noi. În cele mai multe cazuri, în presă se relatează despre infracțiuni aproape invizibile. Totuși, fenomenul se reinventează într-o măsură mai mare și se adaptează fie în spațiul online sau offline, iar adesea instituțiile de resort nu fac față stopării/ diminuării traficului de ființe umane.

Indubitabil, nu doar școala sau familia, dar și sistemul social, și cel judiciar, în ansamblu, trebuie să reacționeze cu măsuri drastice de combatere și să diminueze acest flagel, produs sub diverse forme, inclusiv cea a traficului de ființe umane [11, p. 63].

De facto, cetățenii își construiesc propriile sale versiuni asupra realității în raport cu cultura și societatea căreia aparțin. În cazul victimelor traficului de ființe umane, ei privesc lumea dintr-o perspectivă ușor denaturată. Victima traficului devine vulnerabilă fața de unele oferte de muncă atractive. Aici menționăm și metoda de recrutare lover-boy, ușor pusă în aplicare de către recrutori, deoarece dorința de afirmare a persoanei traficate este mai intensă decât cea de a fi în siguranță.

După cum constructivismul (paradigmă a învățării) pune accentul pe procesele de interpretare a stimulilor care au loc în mintea elevului, exact în acest mod se dorește de a fi abordat și procesul de reintegrare a victimelor traficului de ființe umane. Este, de asemenea, esențial ca măsurile de reintegrare să fie concepute astfel, încât să prevină re-traficarea și să țintească cauzele sociale și economice. De exemplu, este important ca orice servicii de instruire / educaționale oferite să fie relevante în contextul realităților locale. 


\section{Factorii determinanți ai fenomenului traficului de ființe umane}

Referitor la motivele deciziei de a urma studiile unei școli profesionale sau de meserii, răspunsurile la această întrebare adresată unui grup de elevi au fost diferite, dar majoritatea au scos în evidență faptul că nu există o cauză clară, dar anumiți factori externi au influențat într-o măsură mai mică sau mai mare. Motivele cele mai invocate au fost legate de faptul că nu au reușit într-o altă instituție de învățământ, fie liceu sau colegiu.

Se atestă faptul că nivelul educatiei influentează direct gradul de vulnerabilitate a tinerilor, aceste două componente fiind, de fapt, rezultatul altor efecte de ordin psiho-socio-economic. Școala deși reprezintă un mediu protectiv, nu este suficient de bine securizată și nu reprezintă mediul în care un elev poate prelua informația necesară care să asigure securitate și siguranță în luarea deciziilor sale. Respectiv, nivelul de anticipare a riscurilor și de întelegere a fenomenului traficului de fiinte umane este direct legat de educația sa. Informarea limitată, stereotipurile bine impregnate și mixate cu o educație insuficientă constituie una din cauzele principale ce generează oferta infernală de muncă, prin capturarea într-o rețea a comercianților de oameni. Specialiștii susțin că majoritatea victimelor care ajung în asistență din cauza acestui flagel au un nivel de educație limitat, unele sunt chiar analfabete. Pe de altă parte, elevii consideră că pericolul traficului de ființe umane nu-i poate afecta. Ei sunt de părerea că pe ei nu-i paște pericolul de a deveni victime ale traficului de fiinte umane. Ei consideră că bărbații nu pot fi traficați. Reacția băieților, în special, este de a ignora realitatea, convinși fiind că „mie nu mi se poate întâmplă, că au mai fost cunoștințe de-ale mele care au lucrat și au venit și cu bani...".

Se pare că există o contradicție între nevoia de afirmare, câștigurile financiare ale tinerilor, lipsa abilitătilor de muncă si a unui regim de viață stabil. Minorii nu consideră îndeplinirea aspirațiilor și dorințelor lor ca un plan pe termen lung, bazat pe muncă și efort. Tocmai aceste aspecte determină dorința de evadare și de neasumare a responsabilităților pe termen mediu sau lung.

\section{Consecințele traficului de ființe umane asupra tinerilor}

Cu certitudine, experiența de trafic lasă varii amprente asupra diferitelor categorii de victime. Termenii traumă și victimă sunt „utilizați pentru analizarea consecințelor unei experiențe adverse asupra individului" [16, pp. 32-33].
La întoarcerea în țară, dacă este vorba de trafic extern, sau la evadarea din rețeaua criminală internă, din cauza experienței trăite, victimele adesea suportă stări de anxietate, ajung în situații de încercări suicidale, izolare, sentimente și comportamente agresive, stigmatizare, dificultăți în accesarea resurselor, de comunicare cu familia sau cu persoanele de sprijin care pot fi un suport și, de asemenea. Totodată, în atare cazuri, în rândul persoanelor traficate se poate atesta existența unui pattern vicios, legat de consumul de droguri, alcool, fumat excesiv sau, dimpotrivă, acești oameni dovedesc o liniște și un calm bolnăvicios [5, pp. 45-47; 15, p. 37; 16, p. 34].

Problema, însă, devine complicată dacă, în lipsa unei alte locuințe, victima se reîntoarce, în același mediu abuziv sau unde membrii familiei fac parte din rețeaua de trafic, ei înșiși traficând-o. Acesta se întâmplă, de obicei, în contextul în care victimele au fost traficate în scop sexual [9, pp. 42-43].

\section{Percepția vieții și aspirațiile victimelor traficului de ființe umane}

Strategia de viață a tinerilor se formează pe baza percepțiilor, experienței, situației lor în cadrul familiei, școlii sau mediului de apartenență. Valorile acumulate pe parcursul adolescenței, pattern-urile culturale, nevoile de natură socială și economică marchează dorintele și aspirațiile ulterioare ale fiecăruia. Vulnerabilitatea tinerilor față de recrutori este strâns legată de aspirațiile de viață, dorința de obținere de bunuri financiare și beneficii imediate.

Specialiștii atrag atenția că percepțile și aspirațiile de viață sunt diferite și din perspectiva de gen. Lipsa unor părinți-model pentru copii explică situațiile când băieții își asumă rolul de bărbați și iau decizii imature, astfel ajungând să nu anticipeze unele riscuri posibile.

Refuzul de a recunoaște cum stau lucrurile în realitate, incapacitatea de anticipare a evenimentelor posibile si de neasumare a riscurilor sunt doar unele aspecte ce pun în pericol viața tinerilor, inclusiv celor din scolile profesionale. În general, tinerii nu prevăd pericolele ce pot apărea, în timp ce săvârșesc anumite fapte. Ei sunt animați doar de „imaginea pozitivă, în roz" a lucrurilor, acesta fiind un element principal pe care îl preferă în cazul oricărei schimbări de atitudine, actiune sau activitate.

Ușor influențabili, cu un înalt grad de încredere, elevii acceptă orice oferte din partea așa-numiților prieteni, colegi de școală, vecini sau rude. Stereotipurile legate de succes adesea îi fac să adopte o poziție superficială față de propunerile legate de muncă ale unor grupări criminale. Doar informa- 
rea substanțială în prealabil referitoare la riscurile fenomenului traficului de ființe umane poate să-i convingă în privința unor posibile pericole reale în condițiile fenomenului exacerbat.

În cazul fetelor, datorită stereotipurilor legate de rolul femeii în societate și modalitățile de afirmare, ele sunt adesea influențate de false promisiuni, având drept scop bine definit - identificarea unor bărbați care să le asigure confortul.

\section{Concluzii}

Sintetizând informațiile prezentate în cadrul acestui articol, subliniem că principalii factori ce provoacă vulnerabilitatea elevilor față de traficul de persoane, ajungând în situații de risc, se referă, în principal, la mediul de proveniență, nivelul scăzut de trai, educația și limitele surselor informaționale, accesul limitat la învățământul mediu de specialitate și cel superior, precum și probleme legate de identificarea unui loc de muncă conform specialităților. Aspirația pentru o viață decentă, dorința pentru independența financiară (în mod special, în cazul băieților), promisiunile venite din partea recrutorilor, generează starea de incertitudine, șovăială.

\section{Recomandări}

În vederea prevenției și combaterii acestui fenomen în Republica Moldova, recomandăm introducerea în curriculumul școlar a unor teme de studiu privind scrierea și managementul de proiecte, atragerea de fonduri, dezvoltarea planurilor de afaceri, a gândirii critice, ceea ce ar facilita schimbarea atitudinii elevilor față de procesul de obținere pe cale legală a resurselor financiare.

De asemenea, este necesară adaptarea continuă a programelor de studii la solicitările actuale de pe piața muncii. Stereotipurile preluate din mediul de apartenență, informarea insuficientă afectează opțiunile elevilor pentru carierele de viitor. S-a observat că raportul dintre gradul de informare și educație este direct proporțional: elevii cu un nivel scăzut de informare, dar și de educație, devin mai vulnerabili în fața fenomenului traficului de ființe umane.

Campaniile de sensibilizare sunt extrem de necesare pentru prevenirea acestui fenomen. De aceea, recomandăm organizarea unor ample campanii de informare la nivel comunitar privind formele de exploatare a traficului de ființe umane. Din punct de vedere al afirmării profesionale și identificării unui statut social, elevii școlilor profesionale sunt dezavantajați. În afara faptului că au constrângeri socio-economice, aceștia sunt marginalizați doar pentru că au ales de a fi instruiți la respectivele unități de învățământ.

Elevii din cadrul școlilor profesionale suferă de așa-numitele pseudo etichete impuse în plan social, precum că acei care frecventează asemenea instituții pot fi egalați cu persoane neîmplinite, lipsite de șanse de a obține venituri financiare suficiente în Republica Moldova. Acești elevi sunt sortiți eșecului, prin simplul fapt că sunt discriminați.

Or, soluție ar fi reformarea programelor de orientare în carieră, pentru învățământul gimnazial. Aceasta ar contribui la identificarea abilităților precoce a elevilor care doresc să urmeze o școală profesională. Totodată, recomandăm asigurarea angajării unor psihologi și/sau asistenți sociali în școlile gimnaziale și profesionale, care să faciliteze procesul de ghidare în carieră a elevilor, de organizare a activităților de eliminare a stereotipurilor legate de egalitatea de șanse între femei și bărbați.

\section{REFERINTE BIBLIOGRAFICE}

1. ANITP. Traficul de copii în România - studiu asupra procesului de recrutare. Bucuresti: Editura „Alpha MDN2", 2009.

2. Arpinte D., Crețu M. Evaluare rapidă privind traficul de persoane în zonele București, Constanța, Iași și Ialomița. București: „World Vision", 2007.

3. Centrul Internațional „La Strada”. Asistența socială a victimelor traficului de persoane, în special femei. Îndrumar practic pentru asistenți sociali. Chișinău, 2005.

4. Centrul Internațional „La Strada”. Îndrumar practici pentru asistenți sociali și psihologi. Chișinău, 2005.

5. Centrul Internațional „La Strada” Good practices in ensuring adequate assistance to all categories of trafficked persons. The International Centre for Women Rights and Promotion „La Strada”. Chişinău, 2006. 
6. Convenția Consiliului Europei privind lupta împotriva traficului de ființe umane, art. 12, pct. 7. Varșovia, 2005.

7. Date statistice generale privind educația în Republica Moldova, 2015-2016. Chișinău, 2017.

8. Fedor G. Domestic Violence - Risk factor for trafficking in human beings - Secularization and Public Policy Intervention. Iași: Institutul European, 2013.

9. International Organization for Migration. Breaking the cycle of vulnerability, 2006, pp. 42-43.

10.Planul național de acțiuni de prevenire și combatere a traficului de ființe umane din Republica Moldova, Chișinău, 2014-2016.

11.Rădulescu S.M. Devianță, criminalitate și patologie socială. București: Editura „Lumina Lex”, 1999.

12.Toartă, V., Vremeș, M., Abordări ale excluziunii sociale în Republica Moldova. Aspecte metodologice și analitice. Chișinău: Tipografia „Nova Imprim”, 2012.

13. United Nations Office on Drugs and Crime(UNODC), Abuse of a Position of Vulnerability and other "means” within the definition of trafficking in persons, Vienna, 2012.

14.UNODC. Abuse of position of vulnerability and other "means” within the definitions of trafficking in persons. Vienna, 2012.

15.Van Hook M.P., Gjermeni E., Haxhiymeri E. Sexual trafficking of women. Tragic proportions and attempted solutions in Albania. SAGE Publication, 2006.

16. Vechiu A. Nevoile victimelor traficului de persoane în raport cu serviciile oferite de echipa pluridisciplinară, în scopul reintegrării socio-profesionale a victimelor. Iași: Editura „Lumen”, 2009.

17.Zanfirescu L. Social Dimensions of Human Trafficking. In: Human Trafficking. Secularization and Public Policy Intervention. Iași: Institutul European, 2013, p. 26.

18.http://protv.md/stiri/actualitate/cel-putin-17-minore-scapatedin-mainile-traficantilor-de-copii---1056561.html. 